\title{
Difficulties faced by Students in Adopting Arabic Language as Medium of Instruction in International Islamic University Islamabad
}

\author{
Humera Perveen ${ }^{1}$, Muhammad Arshad Dahar ${ }^{2}$
}

\begin{abstract}
The study was conducted to investigate the difficulties faced by students in adopting Arabic language as medium of instruction for the subject of Islamic Studies at International Islamic University Islamabad. The nature of study was descriptive. The objectives of the study were to; find out the proficiency level of students in Arabic language, find out the difficulties faced by students in adopting Arabic language as medium of instruction and to give recommendations to address the difficulties faced by students in adopting Arabic language as medium of instruction. The study was delimited to the Faculty of Usuluddin. Students of BS Usuluddin were the population of the study. Gender based proportionate random sampling technique was used to select the sample of 300 students, comprising 60 students from each of the five departments. Close ended questionnaire was used to collect the data. Data were analyzed using percentage, mean score and Chi-square. Results showed that Pakistani students are not natively Arabic speaker and they do not speak Arabic at home. All the statements of study were highly significant and students feel difficulties in basic language learning skills like reading, writing, speaking, pronunciation and Arabic grammar rules. The study recommended to minimize the difficulties of reading Arabic, vocabulary and understanding Arabic language. Students should read Arabic magazine, newspaper and articles in Arabic and teaching of Arabic should start from simple structure of sentence and to give examples from their daily life, and students may be encouraged to learn Arabic language.
\end{abstract}

Keywords: Arabic Language, Medium of Instruction, Islamic Studies

\section{Introduction}

Arabic is an important language for Muslims all over the world. God's final message to mankind, the Holy Quran, was revealed in Arabic on Holy Prophet Muhammad (PBUH). Arabic is not only an important language in its local countries but it is also important and serious in terms of international

\footnotetext{
${ }^{1}$ M.Phil Scholar, Department of Education, PMAS Arid Agriculture University, Rawalpindi Email: humeraperveen1990@gmail.com

${ }^{2}$ Assistant Professor, Department of Education, PMAS Arid Agriculture University, Rawalpindi Email: arshid1969@hotmail.com
} 
business, economy and international relations. Now-a-days awareness of Arabic is important in the modern political and societal debate. Arabic language, in Pakistan is being taught by some institutions. Pakistani Madrassas focused on Arabic learning but other higher institutions pay less attention on teaching Arabic and adopting Arabic language as a medium of instruction. International Islamic University of Islamabad (IIUI) has adopted Arabic language as medium of instruction for Usuluddin and Shariah and Law. Since, Pakistanis are non-native Arabic speakers and when they adopt Arabic language as medium of instruction they definitely feel many difficulties in basic language skills like reading, writing, speaking, pronunciation, grammar learning and understanding etc.

Difficulties in Arabic are due to the difference between Arabic and their mother tongues. Meanwhile the difference between Arabic and mother tongues is normal for a learner to come across multiple difficulties. These difficulties are at different language levels. One of the problems that a learner may face is the difficulty of distinguishing between the roots and sources of Arabic words likewise another difficulty is to identify the sources of three-letter verbs because they are phonetic and make it easier for an Arab student to begin hearing them at an early age. Therefore, the learner suffers from the difficulty of searching for unfamiliar words in the Arabic dictionary; because it is necessary to know the roots and the sources of the word (Daniel, 2013). The difficulty of pronunciations of letters is a problem for Arabic language learners because many languages in the world do not contain phonemes in independent forms and symbols as in Arabic, so almost Arabic speakers who speak other languages suffer from pronunciation. Students feel difficulties at different levels in learning Arabic language as medium of instruction. Actually, they are non-native Arabic speaker, they can only read Holy Quran and many students don't not know about Qirat when they adopt Arabic as a medium of instruction hence they definitely face many difficulties.

\subsection{Objectives of the Study}

The objectives of this study were:

1. To find out the proficiency level of students in Arabic language.

2. To find out the difficulties faced by students in adopting Arabic language as medium of instruction.

3. To suggest strategies to address the difficulties faced by students.

\subsection{Significance of the Study}

The study is significant for the Pakistani students and teachers in adopting Arabic Language as a medium of instruction as it suggests strategies to address the difficulties faced by students. 


\subsection{Hypotheses of the Study}

$\mathrm{Ho}_{1}$ : There are no significant difficulties for students in Reading skills.

$\mathrm{H}_{\mathrm{O} 2}$ : There are no significant difficulties for students in Speaking skills.

$\mathrm{H}_{\mathrm{O} 3}$ : There are no significant difficulties for students due to teachers, behavior and style.

$\mathrm{H}_{\mathrm{O} 4}$ : There are no significant difficulties for students in Grammar skills.

$\mathrm{H}_{\mathrm{O} 5}$ : There are no significant difficulties for students in Pronunciation skills.

$\mathrm{H}_{\mathrm{O} 6}$ : There are no significant difficulties for students in Writing skills.

\section{Literature Review}

Arabic Language is an important language for Muslims. It is spoken all over the world and now especially in western countries, the number of learners who are learning Arabic is rapidly increasing, it represents Arabic as an international language. In spite of the fact that there is difference in sentence structure of Arabic language in Pakistan and numerous parts of the world. In bilingual training, the learners learn through two languages in the classroom and Arabic language has adopted status of second language in Pakistan. Bilingual instruction through the bilingual reading material, conversational written work from learners in different rules and oral code exchanging amongst instructors and learners in the classroom can create open expressive and thinking abilities (Khattab, 2015).

The impact of first language reading on second language reading can be different in nature. The difference between two languages exists. For a certain something, in first we figure out how to read (i.e. proficiency advancement), while we can attempt to read and to learn in second language (i.e. familiarity advancement). We can judge similarity and difference between languages in light of few variables including time, intentions, requirements, objectives, dispositions, capability level and subjective ability (Grabe 2014). The learners don't realize that they have a real issue in reading neither some instructors know which strategies should be utilized to enable the students to solve the issues about reading (Reid, 2016). Somsai \& Intaraprasert (2011) depicted this condition as irregular collaboration methodologies for passing on a message to the students. They additionally clarified that this technique is typically utilized as a part to analyze correspondence for example when the speaker ignores the delivery of the message to the liquid. The speaker remained silent for some time just to think about the best way to pass the memorandum correctly.

This issue is obvious as well as still for the higher studies learner, as they are extremely confused to converse in Arabic. There are some difficulties such as: multiple meanings in the Arabic language and the use of Arabic dictionaries 
that rely on the root, which have derivatives. Arabic language instruction for speakers in other languages has become a wide area that attracts students from all over the world to learn Arabic (Thornton, 2016). Foreign language learners in Malaysia, especially students of Arabic, Japanese, and other languages, do not respond naturally to take advantage of these remote languages in communication due to their difficult language ability and, consequently, most learner don't apply much power to enhance their Arabic conversation ability (Pandian, Tan \& Sheikh, 2011).

Awang, Mohamed \& Sulaiman (2013) described that International Islamic University Malaysia (IIUM) is a university that provides an environment and is struggling for the advancement of Arabic spoken capabilities. Arabic was spoken consistently, inside and outside the educational institutions. Likewise, there were co-curricular exercises, for example, deliberate circles that require the learner to talk in Arabic. In some cases, there was conflict with the learner reactions on a similar issue. According to the learners, IIUM was not sufficiently favorable to help advance Arabic spoken capabilities. Learners' failure to converse in Arabic as well as lack with regards to discussion's ability. The majority of the learners don't take part in speaking activities. Students are not able to tackle all difficulties.

A large number of non-local speakers encounter challenges to learn Arabic, especially the pronunciation of particular consonant sounds and words including these sounds. Recitation of the Qur'an is a basic foundation of Islamic for religious practice and it isn't possible for Muslims to satisfy the obligation of their self-belief without some information of recognized Arabic because all necessary prayers are being completely in Arabic. In this way, Arabic language is a foundation of all religious instruction, including at educational level (Alsrhid, 2013).

Learners feel difficulty in Arabic pronunciation and vocabulary; however they are not prepared to make use of it in communicating in Arabic language. This issue happens for many components. Among the variables Malay learners had no trust in communicating in Arabic language, the shortcoming of instructional method in Arabic language communication and the impact of the principal language. A few learners simply need to learn Arabic as a moment language for their very own advantage. Concerning articulation, exactly talked Arabic is significant for learners trying to wind up religious pioneers, for example, Imams, and particularly for those learners who intends to proceed with investigations assist by enlisting in the Qur'an workforce. In this way, the significance of exact Arabic voice production for learners at the Institute is huge as their future vocations are possibly connected to it (Al-Issa \& Dahan, 2011). In 
spite of the fact that there has been a tendency for specific techniques at various circumstances, strategies frequently proceed in some shape long after they have dropped out of support; this perception is still valid with sentence structure interpretation strategy that is as yet alive in Pakistan and different parts of the world. In bilingual training, the learners learn through two languages in the classroom (Mackey, 1966).

Rabab'ah \& Bulut (2007) cleared that learner couldn't present their voice since they do not have the enough vocabulary to write a good paragraph. However, techniques for showing English included the medium of instruction, utilizing Arabic in English classes, texting done in Arabic, educators' low competence in English, and absence of writing practice in educational foundations. English language students have low vocabulary. Subsequently, learners repeat similar words in writing activity. Kambal (1980) investigated mistakes in three kinds of free structure by first year Sudanese college learners. The investigation reflected the major syntactic mistakes made by these learners in the verb appearance and the noun appearance. Additionally, Kambal (1980) talked about mistakes in tenses inside five groups: tense series, tense exchange, tense indication, cancellation, and hesitation of perfect tenses. In comparative views, Juma (2014) states that composing method empowers the learners to make clear choice about their composition by specific methodology, for example, dialogue, assignments, drafting, criticism, and educated decisions. The positive position in accepting the procedure is refreshing the significance of the repeating and recursive nature of composing that is utilized by local writers where precomposing, composing, and recomposing often times appear to go repeatedly.

Among the grammar difficulties students face the distinction between verbal and nominal sentences and the distinction between the various letters, conditions, numbers and rules methods. Learners acknowledged that the techniques used for teaching and nature is the primary reason of their shortcomings in language learning. Their weak competency is moreover identified with the absence of learner inspiration, or the educator's advantage. Numerous students utilize their native language due to detachment from culture (Al- Khasawneh \& Maher, 2010).

\subsection{Research Design}

\section{Research Methodology}

The study has investigated the difficulties in adopting Arabic language as a medium of instruction for the subject of Islamic studies. Research design was descriptive in nature employing survey technique. 


\subsection{Population of Study}

Male and female students of all semesters for the session of 2014 to 2017 of BS Usuluddin (Islamic Studies program) of IIUI were population of study. Whole population was 1625 which was consisted on 787 male students and 838 female students.

\subsection{Sample and Sampling Technique}

30 Male and 30 female students from each department of Usuluddin were selected through simple random sampling technique. The whole sample size was comprised of 300 students i.e. 150 male and 150 female students.

\subsection{Instrumentation}

As the nature of study was descriptive therefore questionnaire was developed by the researcher using by five point likert scale as instrument for research.

\subsection{Data Collection}

Researcher thoroughly briefed respondents about the procedure of filling of the questionnaire. Responses from the most of the respondents were appropriate and provide the required data. The data were collected by researcher in session 2017-2018.

\section{Data Analysis \& Interpretation}

According to the demand of objectives and nature of data; mean, Standard deviation, percentage, frequency and chi-square were used.

Table 4.1

Reading Skill

\begin{tabular}{lccccccc}
\hline Gender & & High & Medium & Low & $\mathrm{N}$ & Mean & SD \\
\hline Male & $\mathrm{F}$ & 16 & 80 & 54 & 150 & 2.25 & .63 \\
& $\%$ & 10 & 53 & 36 & & & \\
Female & $\mathrm{F}$ & 38 & 60 & 52 & 150 & 2.12 & .78 \\
& $\%$ & 25 & 40 & 34 & & &
\end{tabular}

Table 4.1 shows that $10 \%$ male students have high proficiency level, $53 \%$ has medium proficiency level and $36 \%$ male students have low proficiency level. $25 \%$ female students have high proficiency level, $40 \%$ has medium proficiency level and 34\% female students have low proficiency level. Overall proficiency level of male and female students in reading skill is medium. 
Table 4.2

Pronunciation Skill

\begin{tabular}{lccccccc}
\hline Gender & & High & Medium & Low & N & Mean & SD \\
\hline Male & $\mathrm{F}$ & 9 & 96 & 45 & 150 & 2.30 & .57 \\
& $\%$ & 3 & 64 & 30 & & & \\
Female & $\mathrm{F}$ & 42 & 58 & 50 & 150 & 2.08 & .79 \\
& $\%$ & 14 & 38 & 33 & & & \\
\hline
\end{tabular}

Table 4.2 shows that 3\% male students have high proficiency level, $64 \%$ has medium proficiency level and 30\% male students have low proficiency level. $14 \%$ female students have high proficiency level, $38 \%$ has medium proficiency level and 33\% female students have low proficiency level. Overall proficiency level of students in Arabic pronunciation skill is medium.

Table 4.3

Writing Skill

\begin{tabular}{lccccccc}
\hline Gender & & High & Medium & Low & N & Mean & SD \\
\hline Male & $\mathrm{F}$ & 5 & 39 & 106 & 150 & 2.73 & .513 \\
& $\%$ & 1 & 13 & 35 & & & \\
Female & $\mathrm{F}$ & 10 & 66 & 72 & 150 & 2.49 & .514 \\
& $\%$ & 3 & 22 & 25 & & & \\
\hline
\end{tabular}

Table 4.3 shows that $1 \%$ male students have high proficiency level, $13 \%$ has medium proficiency level and 35\% male students have low proficiency level. $3 \%$ female students have high proficiency level, $22 \%$ has medium proficiency level and $25 \%$ female students have low proficiency level. Overall proficiency level of students in Arabic writing skill is low.

Table 4.4

Speaking Skill

\begin{tabular}{lccccccc}
\hline Gender & & High & Medium & Low & $\mathrm{N}$ & Mean & SD \\
\hline Male & $\mathrm{F}$ & 05 & 80 & 65 & 150 & 2.43 & .49 \\
& $\%$ & 1 & 21 & 26 & & & \\
Female & $\mathrm{F}$ & 21 & 57 & 72 & 150 & 2.34 & .71 \\
& $\%$ & 7 & 19 & 24 & & &
\end{tabular}

Table 4.4 shows that $1 \%$ male students have high proficiency level, $21 \%$ have medium proficiency level and $26 \%$ male students have low proficiency level. $7 \%$ female students have high proficiency level, $19 \%$ has medium proficiency level and $24 \%$ female students have low proficiency level. Students, proficiency level in Arabic speaking skill is low. 
Table 4.5

Reading Difficulties faced by Learners

\begin{tabular}{llllc}
\hline S\# & \multicolumn{1}{c}{ Statements } & Mean & S.D & $\chi^{2}$ \\
\hline 1. & $\begin{array}{l}\text { Arabic reading without symbols } \\
\text { (Aarab) is difficult. }\end{array}$ & 2.97 & 1.21 & 98.5 \\
2. $\quad \begin{array}{l}\text { I feel difficulty in reading Arabic } \\
\text { books. }\end{array}$ & 2.93 & 1.13 & 258.8 \\
3. I feel difficulty in reading \\
$\begin{array}{l}\text { question paper in Arabic during } \\
\text { exams. }\end{array}$ & 3.71 & 1.06 & 241.8 \\
\hline $\mathrm{df}=4$ & $\alpha=0.05$ & Tabulated Value $=9.35$
\end{tabular}

Table 4.5 shows that values for statement no 1, 2 and 3 are greater than tabulated value so all these statements are accepted. Hol has been rejected and the indicator Reading difficulties faced by learner in learning Arabic is statistically highly accepted. Students feel difficulties in reading Arabic as second language in reading question paper and books without symbols.

Table 4.6

Speaking Difficulties faced by Learners

\begin{tabular}{lllllc}
\hline S\# & \multicolumn{1}{c}{ Statements } & Mean & S.D & $\chi 2$ \\
\hline 1. & $\begin{array}{l}\text { I speak Arabic with my class } \\
\text { fellows. }\end{array}$ & 3.1 & 1.31 & 113.4 \\
2. I try to Speak Arabic with my & 2.8 & 1.23 & 87.1 \\
$\begin{array}{l}\text { teachers. } \\
\text { 3. I feel shy in speaking Arabic. }\end{array}$ & 3.5 & 1.24 & 158. \\
4. It is difficult to learn Arabic & 3.3 & 1.21 & 71.9 \\
$\quad \begin{array}{l}\text { language for those who don't know } \\
\text { any other foreign language. }\end{array}$ & & & \\
In Arabic class I always take part in \\
discussion.
\end{tabular}

Table 4.6 about difficulties faced by learner in Speaking shows that value for statement no 1,2,3,4 and 5 are greater than tabulated value So all these statements are accepted. Ho2 has been rejected and the indicator, speaking difficulties faced by learner is statistically significant. Students cannot speak Arabic with fellows and teachers. They feel shy in speaking Arabic so they cannot participate in group discussion. 
Table 4.7

Grammar Difficulties faced by Learners

\begin{tabular}{ccccc}
\hline $\mathrm{S} \#$ & \multicolumn{1}{c}{ Statements } & Mean & S.D & $\chi^{2}$ \\
\hline 1. & $\begin{array}{l}\text { Learning of Arabic grammar helps me to } \\
\text { understand Arabic. }\end{array}$ & 3.4 & 1.26 & 123.4 \\
2. & $\begin{array}{l}\text { Grammar drill is very important in } \\
\text { mastering a second language. }\end{array}$ & 3.5 & 1.22 & 98.7 \\
3. & $\begin{array}{l}\text { I think Arabic grammar learning is difficult } \\
\text { for everyone. }\end{array}$ & 2.9 & 1.23 & 158.0 \\
\hline $\mathrm{df}=4$ & $\alpha=0.05$ level & Tabulated Value $=9.35$
\end{tabular}

Table 4.7 about Grammar difficulties faced by learner shows that values for statement no 12 , and 3 are greater than tabulated value so all these statements are accepted. Ho3 is rejected and the indicator grammar difficulties faced by learner, is statistically significant. Arabic language is hard by nature and its rules are very complicated. Grammar drill is very important for language learning.

Table 4.8

Pronunciation Difficulties faced by Learners

\begin{tabular}{llllc}
\hline S\# & \multicolumn{1}{c}{ Statements } & Mean & S.D & $\chi 2$ \\
\hline 1. & I feel shy in pronunciation of words. & 3.4 & 1.18 & 188.4 \\
2. & $\begin{array}{l}\text { I remain calm when I cannot pronounce } \\
\text { any word correctly. }\end{array}$ & 3.1 & 1.23 & 149.3 \\
3. & $\begin{array}{l}\text { My class fellows laugh at me whenever I } \\
\text { pronounce any word wrong. }\end{array}$ & 3.4 & 1.23 & 190.1 \\
4. $\quad \begin{array}{l}\text { I think symbols are useful for learning } \\
\text { correct pronunciation. }\end{array}$ & 3.4 & 1.20 & 239.5 \\
5. $\quad \begin{array}{l}\text { I use dictionary to know the pronunciation } \\
\text { of words. }\end{array}$ & 2.7 & 1.24 & 127.1 \\
\hline $\mathrm{df}=4$ & $\alpha=0.05$ level Tabulated Value $=9.35$
\end{tabular}

Table 4.8 about Pronunciation difficulties faced by learner shows that values for statement no $12,3,4$ and 5 are greater than tabulated value so all these statements are accepted. Ho4 is rejected and the indicator grammar difficulties faced by learners, is statistically significant. 
Table 4.9

Writing Difficulties faced by Learners

\begin{tabular}{llllc}
\hline S\# & \multicolumn{1}{c}{ Statements } & Mean & SD & $\chi^{2}$ \\
\hline 1. & $\begin{array}{l}\text { Lack of Arabic writing activities is } \\
\text { reason for poor writing. }\end{array}$ & 3.3 & 1.3 & 197.1 \\
2. & $\begin{array}{l}\text { I feel difficulty while sentence } \\
\text { structure. }\end{array}$ & 3.4 & 1.2 & 190.1 \\
3. & $\begin{array}{l}\text { I feel difficulty in writing Arabic } \\
\text { due to weak vocabulary. }\end{array}$ & 3.7 & 1.1 & 213.7 \\
4 feel difficulty in writing a \\
$\begin{array}{l}\text { paragraph. } \\
\text { df }=4\end{array} \quad \alpha=0.05$ level & Tabulated Value $=9.35$
\end{tabular}

Table 4.9 about Writing difficulties faced by learner shows that that values for statement no 1, 2, 3, 4, 5 and 6 are greater than tabulated value so all these statements are accepted. Ho5 is rejected and the indicator writing difficulties faced by learners is statistically significant.

\section{Discussion}

At very fist level it is difficult for students to read correct Arabic without symbols because Pakistani students are non-Arabic learners so they feel difficulty in reading Arabic. Grabe (2002) supported the statement that they should consider non-native Arabic learners. Students feel shy because other students laugh at them when they pronounce any word wrong therefore they try to remain quite in classroom and outside the classroom. Tanveer (2007) and Haron et al. (2016), stressed on encouragement of students. Pronunciation of Arabic alphabets is totally different from pronunciation of Urdu and English, however as Muslim country, Pakistani students can read Arabic but unfortunately mostly students pronounce Arabic just like Urdu because in Urdu mostly words are adopted from Arabic. Results of study are in line with the findings of Ismail $\& \mathrm{~Pa}$ (2006) and Macaro (2001). Due to lack of opportunity of speaking inside classroom and outside the classroom, students face difficulty in Arabic speaking. Mat Taib (2006) also emphasized the use of the communicative approach in instructing Arabic speaking because non-native learners have no opportunity of speaking Arabic at home due to which speaking skills of students cannot strengthen. He also emphasizes on communicative approach for enhancement of Arabic speaking skills. However, Urdu grammar is similar at some points to Arabic but English grammar is totally different from Arabic and due to differences between the grammatical structures of students' first language and second language, students feels difficulty in grammar learning. This result is also 
supported by Sawir (2005). Mostly students feel difficulty in writing Arabic due to weak vocabulary so that they cannot write a good paragraph. Alsrhid (2013) supported the result and explained that non-native students feel difficulty in writing Arabic language because they are not Arabic speaker and their Arabic vocabulary is weak because they don't use Arabic in their daily lives and they have no interaction with others who speaks Arabic.

\section{Conclusion}

From the study it has been concluded that students have medium proficiency level in reading and pronunciation and low proficiency level in speaking and writing Arabic. Moreover, reading Arabic without symbols (Aarab) is difficult for students and students also feel difficulty in reading question paper during exam. Pakistan is non-native Arabic country, so students cannot understand Arabic without Aarab. They feel shy in speaking Arabic with students and teachers. As they are not native Arabic speaker so if they speak something wrong other students laugh at them. Arabic grammar is difficult for students and grammar drill is important for learning Arabic language. Students feel difficulty in writing Arabic sentence structure and they cannot write a good paragraph due to weak vocabulary.

\section{Recommendations}

1.To minimize the difficulties of reading Arabic, vocabulary and understanding Arabic language, students should read Arabic magazine, newspaper and articles in Arabic.

2. For teaching Arabic grammar, teacher should take start from simple structure of sentence without providing framework and should use different methodologies for teaching Arabic grammar and should gave examples from their daily lives.

3.Teachers should encourage students and make them confident in classroom however they speak or pronounce any word wrong, like this they become able to participate in class room activities, discussion and will learn better.

4.For improvement of writing, assignment should be given in handwriting instead of print form and presentation should be on board in hand writing instead of multimedia, through this students Arabic writing can improved.

\section{References}

Al-Issa, A., \& Dahan, L. S. (2011). Global English and endangered Arabic in the United Arab Emirates. Global English and Arabic: Issues of language, culture, and identity, 31, 1-22. 
Al-Khasawneh, F. M. S., \& Maher, S. (2010). Writing for academic purposes: Problems faced by Arab postgraduate students of the college of business, UUM. ESP World, 9(2), 1-23.

Alsrhid, A. M. M. (2013). Difficulties face by foreign students in learning Arabic language programs for non-native speakers (Evaluation Study). Learning, 4(2), 160-170.

Awang, N. A., Mohamed, M. H., \& Sulaiman, R. (2013). Enhancing Arabic Speaking Skills among Malay Students through Group Work Activities. International Journal of Humanities and Social Science, 3(21), 212-219.

Daniel, I. O. A. (2013). Language as a Power Positioning Tool: National Open University of Nigeria (NOUN) English Course Materials as Genderised Examples. Journal on English Language Teaching, 3(3), 7-15.

Grabe, W. (2002). Dilemmas for the development of second language reading abilities. Cambridge University Press.

Grabe, W. (2014). Key Issues in L2 Reading Development. Proceedings of the $4^{\text {th }}$ CELC Symposium for English Language Teachers-Selected Papers, 818.

Haron, S. C., Ahmed, I. H., Mamat, A., Ahmad, W. R. W., \& Rawash, F. M. M. (2016). Challenges in Learning to Speak Arabic. Journal of Education and Practice, 7(24), 80-85.

Ismail, M. R., \& Pa, M. T. (2006). Introduction to the linguistic juxtaposition between the Malaysia language and Arabic language. Pengajaran Dan Pembelajaran Bahasa Arab di Malaysia, 1, 111-145.

Juma'Abu-Irmies, A. (2014). Difficulties of Teaching Arabic to Speakers of Other Languages in Jordan (MA Thesis). Faculty of Arts and Sciences, Department of English Language and Literature, Middle East University.

Kambal, M. (1980). An Analysis of Khurtoum University Studentsr Composition Errors (Doctoral dissertation). University of Texas, USA.

Khattab, A. (2015). How Arab executives learn. Michigan State University. 
Macaro, E. (2001). Analysing student teachers' codeswitching in foreign language classrooms: Theories and decision making. The Modern Language Journal, 85(4), 531-548.

MacKey, W. F. (1966). Language Teaching Analysis. London.

Mat Taib Pa. (2006). Dasar-dasar umum pengajaran Bahasa Arab di Malaysia [General principles of Arabic Language teaching in Malaysia]. In Mohd. Rosdi Ismai \& Mat Taib Pa (Eds.), Pengajaran dan pembelajaran Bahasa Arab di Malaysia [The teaching and learning of the Arabic Language in Malaysia]. Kuala Lumpur: University Malaya publications.

Pandian, A., \& Tan, S. S. B., \& Malik, S. A. (2011). Teaching and learning language: Current trends and practices. Universiti Sains Malaysia: Pulau Pinang.

Rabab'ah, G., \& Bulut, D. (2007). Compensatory strategies in Arabic as a second language. Poznań Studies in Contemporary Linguistics, 43(2), 83-106.

Reid, G. (2016). Dyslexia: A practitioner's handbook. John Wiley \& Sons.

Sawir, E. (2005). Language difficulties of international students in Australia: The effects of prior learning experience. International Education Journal, 6(5), 567-580.

Somsai, S., \& Intaraprasert, C. (2011). Strategies for coping with face-to-face oral communication problems employed by Thai university students majoring in English. GEMA Online ${ }^{\circledR}$ Journal of Language Studies, 11(3), 83-96.

Tanveer, M. (2007). Investigation of the factors that cause language anxiety for ESL/EFL learners in learning speaking skills and the influence it casts on communication in the target language (M.Ed ELT Thesis). University of Glasgow, Scotland, UK

Thornton, H. (2016). Topics in the Syntax and Semantics of Infinitives and Gerunds. Routledge. 
International Journal of Innovation in Teaching and Learning (IJITL)

Volume V- Issue II (Dec 2019)

\section{Citation of this Article:}

Perveen, H., \& Dahar, M. A., (2019) Difficulties faced by Students in Adopting Arabic Language as Medium of Instruction in International Islamic University Islamabad. International Journal of Innovation in Teaching and Learning (IJITL), 5(2), 91-104. 